American Journal of Applied Sciences 6 (7): 1380-1384, 2009

ISSN 1546-9239

(C) 2009 Science Publications

\title{
Regionalism and Its Effects on Iranian Agricultural Exports: The Case of Economic Cooperation Organization
}

\author{
${ }^{1}$ Mandana Toosi, ${ }^{1}$ Reza Moghaddasi, ${ }^{2}$ Saeed Yazdani and ${ }^{3}$ Majid Ahmadian \\ ${ }^{1}$ Department of Agricultural Economics, Science and Research Branch, \\ Islamic Azad University, Tehran, Iran \\ ${ }^{2}$ Department of Agricultural Economics, University of Tehran, Iran \\ ${ }^{3}$ Faculty of Economics, Tehran University, Tehran, Iran
}

\begin{abstract}
Problem statement: World economy has become increasingly integrated. There is an underlying assumption that integration into the world economy provides more opportunities for trade. The evidence shows that integration at the regional levels can help developing countries to prepare for the international economic integration. It will be important to outline and analyze past efforts at regional integration (regionalism) to have prospects for future arrangements. Approach: Therefore this study assessed the impact of Iran membership in Economic Cooperation Organization (ECO) on agricultural exports by means of generalized gravity model. The econometric method was used to isolate and eliminate the regional agreement effects is panel and pooled data techniques. Results: Our estimation results indicated positive and significant intra-trade impact of regionalism on Iranian agricultural export. Conclusion/recommendation: We had seen that, directly and indirectly, ECO could have positive effect on Iran agricultural trade. Indirectly, because similarity degree between Iran and the other ECO members in religion, border, ethnic, language and is very high in relation to the other chosen trade partners of Iran. Also a considerable share of the variability in ECO agricultural trade flows referred to uneconomic factors. Therefore, it seems that Iran would be able to expand its agricultural exports by gradually reducing trade barriers in ECO region and using of these ECO members' similarities.
\end{abstract}

Key words: Regionalism, gravity model, agriculture, ECO, Iran

\section{INTRODUCTION}

The world economy after World War II has become much more integrated. The first 20-30 years after World War II can be seen as a period characterized by shallow integration both globally and regionally ("old regionalism"). With the Uruguay round of GATT negotiations, there were strong elements of deep integration ("new regionalism") $)^{[7]}$.

According to the World Trade Organization (WTO), there are over 250 Regional Trade Agreements (RTAs) currently in force. Most of these agreements have been concluded in the past 15 years and many new agreements are under negotiation ${ }^{[11]}$.

Direction of trade data also show that Asia, as the third hub of world trade after Europe and North America, has become increasingly integrated ${ }^{[4]}$.Iran as an Asian developing country has also regionalism and integration experiences such as ECO membership.
ECO includes Afghanistan, Azerbaijan, Kazakhstan, Kyrgyzstan, Tajikistan, Turkmenistan, Uzbekistan as well as Iran, Pakistan and Turkey. Originally initiated by Pakistan, Iran and Turkey in 1985, it aims at the progressive removal of trade barriers; the promotion of intra-regional trade; and the gradual integration of the economies of its Member States with the world economy. An ECO Trade Agreement was signed by five members (Afghanistan, Iran, Pakistan, Tajikistan and Turkey) in July 2003 in Islamabad. Yet in order to become operational, it needs ratification by at least five countries ${ }^{[22]}$. As one of the objectives of the ECO is expansion of intra-regional trade and trade of the region with the rest of the world, it is very important having a better view on how economic integration affects the economic structure specially commodities trade of the region's members. It would show the strong and weak points of region operation and provide inputs for developing a joint trade strategy. It is possible by studying situation of

Corresponding Author: Mandana Toosi, Department of Agricultural Economics, Science and Research Branch, Islamic Azad University, Tehran, Iran 
member countries before and after RTA formation in the region compared with the rest of the world.

In the literature there are numerous studies analyzing the economic impacts of RTAs ${ }^{[8]}$. RTAs might be expected to increase trade between partners, since cheaper import within the agreement may replace domestic production ("trade creation") or crowed out imports from the rest of the world ("trade diversion") ${ }^{[17,23]}$. The gravity model has performed remarkably well as a tool for measuring the impacts of $\mathrm{RTAs}^{[14]}$. Most applications of the gravity model search for evidence of actual or potential effects by adding dummy variables for common languages, common land borders and for the presence or absence of a $\mathrm{RTA}^{[1,19]}$. Some researchers distinguish between the increase in the volume of trade within the bloc and decrease in trade from countries outside the bloc by including two dummies for intra-bloc and extra-bloc trade ${ }^{[14,20]}$.

As agriculture is an important sector for all of the ECO Member States playing a key role in employment, exports, food security and catalyzing other sectors, the objective of this study, therefore, is to assess the impact of Iran membership in economic cooperation organization on agricultural exports by using generalized gravity model.

\section{MATERIALS AND METHODS}

Originally inspired by Newton's gravity equation in physics, the gravity model has become common knowledge in regional science for describing bilateral trade flows and analyzing the effects of regional trade agreements on trade flows to stress the role of regionalization. In the standard model, trade between two countries is viewed as being positively affected by the economic mass of trading partners and negatively affected by the distance between them. Additional variables, such as population, common border, common language, common religion are usually added to empirical gravity models to elaborate on the economic mass and distance variables that is called generalized gravity model. It has also included dummy variables in order to indicate whether a regional trade agreement is effective or not.

The gravity model was first proposed independently by Tinbergen ${ }^{[21]}$ and Poyhone ${ }^{[18]}$.But these studies were criticized for their lack of robust theoretical foundations. This shortcoming has been addressed by a series of studies ${ }^{[2,3,5,6,9,10,15,16]}$. Linneman ${ }^{[16]}$ was the first researcher who tried to provide theoretical foundations based on partial equilibrium model of export supply and import demand. Anderson ${ }^{[2]}$ uses Armington preferences in a model of homogenous goods to derive a role for transport costs, modeled iceberg fashion and on the assumption that distance and transport costs are related. Bergstrand's studies $^{[5,6]}$ develop the Linneman's analysis further. Deardorff ${ }^{[9]}$ found a relation between Heckscher-Ohlin Model and gravity model. Evenett and Keller ${ }^{[12,13]}$ investigated perfect specialization in Heckscher-Ohlin and Increasing Returns to Scale model and found them supportive of gravity model. The recent study of Eaton and Kortum ${ }^{[10]}$ also uses an iceberg framework with homogenous goods but embeds gravitational forces in a Ricardian setting. But, of course, much of recorded trade is in differentiated goods. Helpman and Krugman $^{[15]}$ address this by embedding the equation in a model of monopolistic competition with increasing returns to scale, which also has the virtue of yielding predictions regarding the sectoral pattern of trade.

As stated above the Generalized Gravity Model equation is of the form:

$$
\begin{aligned}
\operatorname{Ln} X_{i j}= & \operatorname{Ln} A+\operatorname{Ln} Y_{i}+\operatorname{Ln} Y_{j}+\operatorname{Ln} N_{i}+\operatorname{Ln} \\
& N_{j}+\operatorname{Ln~} D_{i j}+A_{k} D_{k}+U
\end{aligned}
$$

Where:

$\operatorname{Ln} X_{\mathrm{ij}}=$ The $\log$ of exports from country $\mathrm{i}$ to country $\mathrm{j}$

Ln $Y_{i(j)}=$ The log of country $i(j)$ 's income (normally GDP)

$\operatorname{Ln} \mathrm{N}_{\mathrm{i}(\mathrm{j})}=$ The population of country $\mathrm{i}(\mathrm{j})$

$\mathrm{LnD}_{\mathrm{ij}}=$ The log of distance between $\mathrm{i}(\mathrm{j})$,

$\mathrm{D}_{\mathrm{k}} \quad=$ Dummies $(\mathrm{k}=1, \ldots)$ capturing geographical, regional and cultural effects, $\mathrm{U}$ error-term

Also, there can be other explanatory variables in the gravity model that capture positive benefits from RTA membership (Trade Creation), potential negative benefits from one party a member of a RTA and the other party not a member (trade diversion).

In this study total agricultural exports are concerned and we use a log-linearized gravity equation expressed as follows:

$$
\begin{aligned}
& \operatorname{Ln}\left(X_{\mathrm{ij}}^{\mathrm{a}}\right)=\alpha_{0}+\alpha_{1} \operatorname{Ln}\left(\mathrm{GDP}_{\mathrm{it}}\right)+\alpha_{2} \operatorname{Ln}\left(\mathrm{GDP}_{\mathrm{jt}}\right)+ \\
& \alpha_{3} \operatorname{Ln}\left(\mathrm{POP}_{\mathrm{it}}\right)+\alpha_{4} \operatorname{Ln}\left(\mathrm{POP}_{\mathrm{it}}\right)+\alpha_{5} \operatorname{Ln}\left(\mathrm{DIS}_{\mathrm{ij}}\right)+ \\
& \alpha_{6} \mathrm{LANG}_{\mathrm{ij}}+\alpha_{7} \mathrm{BOR}_{\mathrm{ij}}+\alpha_{8} \mathrm{REL}_{\mathrm{ij}}+ \\
& \alpha_{9} \text { LANDLOCK }_{\mathrm{j}}+\alpha_{10} \text { ETHNIC }_{\mathrm{ij}}+ \\
& \alpha_{11} \mathrm{ECO}+\mathrm{U}_{\mathrm{ijt}}
\end{aligned}
$$

Where:

subscript $\mathrm{i}=$ Refers to Iran

subscript $\mathrm{j}=$ The importers

subscript $\mathrm{a}=$ The agricultural sector

subscript $\mathrm{t}=$ Time

$\mathrm{X} \quad=$ The export flows

GDP $=$ The gross domestic product

POP = The population

DIS $\quad=$ The distance between capital cities 
To control for observable country-pair specific factors affecting bilateral trade, the model includes some dummy variables. LANG, BOR, REL and ETHNIC are four binary variables set to unity if Iran and its trade partners share a common or similar language, border, religion or ethnic, respectively. LANDLOCK is a binary variable which is unity if importer is landlocked. ECO is a dummy variable set to unity if importer is a member of economic cooperation organization.

The generalized gravity model is applied using panel data for the period 1997-2006 for 29 countries (ten members of economic cooperation organization, USA, Russia, China, India and Fifteen Members of European Union). Data on export values for the total agricultural products (aggregation of 24 chapters of HS1996 Tariff Classification) are obtained from the COMTRADE UN data set which includes whole commodities by tariff classifications for all countries expressed in thousands of USD. GDP and population data are taken from international financial statistics and World integrated trade solution data set. Data about the physical distance between two countries come from the leading internet travel and technology company based in Indonesia. Other created variables like common language, common border, common religion, landlocked and ethnic similarities with values 0 and 1 which takes into account similarities between Iran and chosen countries, are taken from the CIA World Factbook.

\section{RESULTS}

In this analysis as a starting point we first estimate gravity model with main variables. Agricultural export values from Iran to 28 chosen countries as a dependent variable is regressed on factor income for exporter and importer countries $\left(\mathrm{GDP}_{\mathrm{i}}, \mathrm{GDP}_{\mathrm{j}}\right)$, population for exporter and importer countries $\left(\mathrm{POP}_{\mathrm{i}}, \mathrm{POP}_{\mathrm{j}}\right)$ and distance between two countries $\left(\mathrm{D}_{\mathrm{ij}}\right)$. In this study the unit root test is first processed.

Since the data are all panel in this investigation, Levin, Lin and Chu technique is employed for the panel unit root test. The result of the stationary test for all variables showed that unit root null hypothesis is rejected and they are stationary. We used OLS estimator, one-way FEM and one-way REM. Making a comparison between OLS and FEM estimators the F test of restricted versus unrestricted models is necessary to decide the individual country's effects are included or not. If they were included, there is a need to decide whether these effects are as fixed or randomly distributed across cross-sectional units. The decision between FEM and REM can be based on Hausman test.
At the second we estimate gravity model with main and dummy variables to show regionalism effects. In addition to regionalism dummy variable, we use others that mentioned above since the similarity between Iran and the other ECO members in religion, border, ethnic, language and is very high in relation to the other trade partners of Iran. In this case a set of dummy variables will make it possible to increase robustness of OLS estimators. Because of high collinearity between dummy variables and random individual effects, REM estimator is not efficient. Serial correlation was not found in the models, as indicated by the Durbin Watson value. Table 1 show the GLS, FEM and REM estimates of the basic gravity model. GLS and FEM results indicate the model fits the data well and basic variables explains more than 90 percent of the variation in bilateral trade across our sample of trade partners of Iran. Restricted versus unrestricted models test showed FEM restimator is more efficient. On the other hand this test results showed that employing data in this study is panel data. As mentioned above, Chi-sq Statistic in Hausman test showed that random effect estimator is more efficient compared with fixed effect.

Table 1: The Results of the estimation

\begin{tabular}{|c|c|c|c|c|c|}
\hline \multirow[b]{2}{*}{ Variable } & & \multicolumn{4}{|c|}{ Dependent variable: $\operatorname{Ln} \mathrm{X}_{\mathrm{ij}}$} \\
\hline & & GLS & \multicolumn{2}{|l|}{ FEM } & REM \\
\hline $\mathrm{C}$ & & $\begin{array}{c}-16.72 * * * \\
(6.56)\end{array}$ & \multicolumn{2}{|c|}{$\begin{array}{l}6.37 * * * \\
(0.45)\end{array}$} & $\begin{array}{l}-6.30 \\
(8.99)\end{array}$ \\
\hline $\operatorname{Ln}_{\text {GDP }}$ & & - & \multicolumn{2}{|c|}{$0.47 * * *$} & $\begin{array}{l}- \\
-\end{array}$ \\
\hline $\operatorname{Ln} \mathrm{GDP}_{\mathrm{j}}$ & & $\begin{array}{l}0.06^{* * *} \\
(0.03)\end{array}$ & \multicolumn{2}{|c|}{$0.04 * *$} & $\begin{array}{c}0.23^{*} \\
(0.12)\end{array}$ \\
\hline Ln $\mathrm{POP}_{\mathrm{i}}$ & & $\begin{array}{l}7.59 * * * \\
(1.48)\end{array}$ & \multicolumn{2}{|l|}{-} & $\begin{array}{l}7.23^{* * *} * \\
(1.80)\end{array}$ \\
\hline $\operatorname{Ln} \mathrm{POP}_{\mathrm{j}}$ & & $\begin{array}{l}0.15^{* * * *} \\
(0.02)\end{array}$ & \multicolumn{2}{|c|}{$0.07 * *$} & $\begin{array}{l}0.25^{* * *} * \\
(0.09)\end{array}$ \\
\hline Ln $D_{i j}$ & & $\begin{array}{l}-0.87 * * * \\
(0.16)\end{array}$ & \multicolumn{2}{|l|}{-} & $\begin{array}{l}-2.10 * * * \\
(0.49)\end{array}$ \\
\hline R-squared & & 0.96 & \multicolumn{2}{|l|}{0.98} & 0.38 \\
\hline \multirow[t]{2}{*}{ F stat } & & $\begin{array}{c}2.19 \\
173.80^{* * * *}\end{array}$ & \multicolumn{2}{|c|}{$174.48 * * *$} & $\begin{array}{c}1.32 \\
12.67 * * *\end{array}$ \\
\hline & $\mathrm{FE}$ & $\mathrm{RE}$ & & $\mathrm{FE}$ & $\mathrm{RE}$ \\
\hline Afghanistan & 3.48 & 0.21 & USA & 0.290 & -1.91 \\
\hline Azerbaijan & 1.73 & -0.74 & Russia & 2.750 & 0.87 \\
\hline Kazakhstan & 0.15 & 0.26 & India & 0.799 & -0.51 \\
\hline Kyrgyzstan & -1.02 & -0.33 & China & -0.370 & -0.11 \\
\hline Pakistan & 1.42 & 0.39 & Austria & -0.720 & -0.08 \\
\hline Tajikistan & 0.09 & 0.94 & Belgium & -0.470 & 0.51 \\
\hline Turkey & 1.38 & 0.04 & Denmark & -1.980 & -1.06 \\
\hline Turkmenistan & 1.32 & -0.49 & Finland & -2.480 & -1.65 \\
\hline Uzbekistan & 0.14 & -0.29 & France & 0.880 & 1.56 \\
\hline Germany & 2.54 & 2.49 & Netherlands & -0.550 & 0.22 \\
\hline Ireland & -3.63 & -1.93 & Portugal & -3.030 & -0.84 \\
\hline Italy & 1.22 & 1.10 & Spain & 2.020 & 2.57 \\
\hline Luxembourg & -0.19 & 0.11 & Sweden & -0.950 & -0.67 \\
\hline UK & 0.18 & 0.18 & Greece & -0.970 & -0.84 \\
\hline
\end{tabular}


Table 2: Results of the pooled estimation procedure with dummy variables

\begin{tabular}{|c|c|c|c|}
\hline \multirow[b]{2}{*}{ Main variable } & \multicolumn{3}{|c|}{ Dependent variable: $\mathrm{Ln} \mathrm{Xij}$} \\
\hline & Coefficients & Dummy variable & Coefficients \\
\hline $\mathrm{C}$ & $\begin{array}{l}17.88 * * * \\
(2.52)\end{array}$ & $\mathrm{ECO}$ & $\begin{array}{l}2.14 * * * \\
(0.39)\end{array}$ \\
\hline $\operatorname{Ln} \mathrm{GDP}_{\mathrm{j}}$ & $\begin{array}{l}0.04 * \\
(0.02)\end{array}$ & $\mathrm{REL}_{\mathrm{ij}}$ & $\begin{array}{c}0.48^{*} \\
(0.25)\end{array}$ \\
\hline Ln $\mathrm{POP}_{\mathrm{j}}$ & $\begin{array}{l}0.14 * * * \\
(0.03)\end{array}$ & $\mathrm{BOR}_{\mathrm{ij}}$ & $\begin{array}{l}2.77 * * * \\
(0.38)\end{array}$ \\
\hline $\operatorname{Ln} D_{i j}$ & $\begin{array}{l}-1.49 * * * \\
(0.29)\end{array}$ & ETHNIC $_{\mathrm{ij}}$ & $\begin{array}{l}0.76^{* * * *} \\
(0.27)\end{array}$ \\
\hline R-squared & 0.96 & & \\
\hline Durbin-watson & 2.15 & & \\
\hline F stat & $159.20 * * *$ & & \\
\hline
\end{tabular}

Table 1 (REM results) show basic variables explain only about $40 \%$ of the variation in bilateral agricultural trade across our sample. The model coefficients had the expected signs but the log of Iran's GDP was not significant. The $\operatorname{logs}$ for both Iran and Importer country's population had the expected sign $(+)$ and were both highly significant (significant in $1 \%$ of probability area). Table 2 shows the GLS estimates of our generalized gravity model with the dummy variables. The significant variables in this model (includes basic and dummy variables) explain 96 percent of the variation in Iran agricultural export flows. It is interesting to note that in the case of GDP, the log of GDP for Iran was insignificant and for the importing countries was positive and significant. Another determinant of agricultural exports is the population of the respective trading pair. In our model we saw highly significant only in the population for the importing country (j).

\section{DISSCUSION}

Because of the log-log nature of the model, the variable coefficient value is the elasticity. According to Table 1 (REM results ), with a $1 \%$ increase in Iran's population there would be $7.23 \%$ increase in Iran agricultural exports and with a $1 \%$ increase in Importer's population there would be a $0.25 \%$ increase in agricultural export flows between Iran and its trade partners.

The log of distance had the expected sign (-) and was highly significant. With a $1 \%$ increase in distance between Iran and Importer $\mathrm{j}$, there would be a $2.7 \%$ decrease in Iran agricultural exports to importers.

The results of the GLS estimation (Table 2) show that the log of distance had the expected sign (-) and was highly significant. With a $1 \%$ increase in distance between Iran and Importer $\mathrm{j}$, there would be a $1.49 \%$ decrease in Iran agricultural exports to importers. Between dummy variables in our model Common Border, Common Religion and Ethnic Similarities were positive and significant. Common language is expected to reduce transaction costs as speaking the same language helps facilitate trade negotiations. But in this study Common Language was insignificant, indicating that language similarity between a trading pair in ECO does not play important role. Landlocked is insignificant, either, showing that the lack of ocean ports did not reduce agricultural trade.

We found that the dummy variable (ECO) for intra-regional exports was positive and highly significant statistically. The coefficient on the dummy variable for regional trading is 2.14 , implying that the ECO regional trading arrangements increase agricultural trade of Iran with ECO members in comparison with other trading partners

\section{CONCLUSION}

As agricultural products are closely related to food security, poverty eradication and rural development, there are special treatment for agricultural products. Thus this study addressed the main question of what effect regionalism have had on agricultural trade. To answer this question we have estimated both standard and generalized gravity model that shows the effective factors on Iran agricultural exports with a special concentration on economic cooperation organization.

We have seen that, directly and indirectly, ECO could have a positive effect on Iran agricultural trade. Indirectly, because similarity degree between Iran and the other ECO members in religion, border, ethnic, language and is very high in relation to the other chosen trade partners of Iran. Also making a comparison between standard and generalized gravity model results (Table 1: REM and 2) showed that a considerable share of the variability in ECO agricultural trade flows refers to uneconomic factors. This study also showed that Tajikistan, Pakistan, Kazakhstan and Azerbaijan in $\mathrm{ECO}$ region are more interested in importing agricultural products from Iran, respectively.

This study can be extended in several ways. First, to estimate the regional impact on a more disaggregated level data or for some specific product groups. Second, to estimate the regional impact on trade of whole ECO members. Another possible extension is to add other variables to the model for showing trade policy impacts of ECO trade agreement (ECOTA). 


\section{REFERENCES}

1. Agostino, M.R., F. Aiello and P. Cardamone, 2007. Analyzing the impact of trade preferences in gravity models. Does Aggregation Matter? http://ideas.repec.org/p/ags/tragwp/7294.html

2. Anderson, J.E., 1979. A theoretical foundation for the gravity equation. Am. Econ. Rev., 69: 106-116. http://ideas.repec.org/a/aea/aecrev/v69y1979i1p10 6-16.html

3. Anderson, J.E. and E. Van Wincoop, 2003. Gravity with gravitas: A solution to the border puzzle. Am. Econ. $\quad$ Rev., 91: 170-192. http://ideas.repec.org/a/aea/aecrev/v93y2003i1p17 0-192.html

4. Asian Development Bank, 2009. Asian development outlook 2009: Rebalancing Asian's growth.

http://www.adb.org/Documents/Books/ADO/2009/

5. Begstrand, J.H., 1985. The gravity equation in international trade: Some microeconomic foundations and empirical evidence. Rev. Econ. Stat., 67: 474-481. http://ideas.repec.org/a/tpr/restat/v67y1985i3p47481.html

6. Begstrand, J.H., 1989. The generalized gravity equation, monopolistic competition and the factor proportions theory in international trade. Rev. Econ. Stat., 71: 143-153.

http://ideas.repec.org/a/tpr/restat/v71y1989i1p143 $-53 . h t m l$

7. Burfisher, M.E., R. Robinson and K. Thierfelder, 2003. Regionalism: Old and new, theory and practice. Proceeding of the International Agricultural Trade Research Consortium Conference, June 23-26, Capri, Italy, pp: 1-31. http://www.ifpri.org/pubs/confpapers/2003/burfish errobinsonthierfelder.pdf

8. Cipollina, M. and L. Salvatici, 2006. Reciprocal trade agreements in gravity model: A meta-analysis. http://papers.ssrn.com/sol3/papers.cfm?abstract_id $=950929$

9. Deardorff, A.V., 1998, Determinants of Bilateral Trade: Does Gravity Work in a Neoclassical World? In: The Regionalization of the World Economy, Frankel, Ed., University of Chicago Press, Chicago, pp: 7-22.

10. Eaton, J. and S. Kortum, 2001. Technology, trade and growth: A unified framework. Eur. Econ. Rev., 45: 742-755.

http://linkinghub.elsevier.com/retrieve/pii/S001429 2101001295

11. Estevadeordal, A., C. Freund and E. Ornelas, 2008. Does Regionalism affect trade liberalization toward nonmembers?

http://ideas.repec.org/p/cep/cepdps/dp0868.html
12. Evenett, S.J. and W. Keller, 1998. On theories explaining the success of the gravity equation. NBER Working Paper, No W6529, National Bureau of Economic Research, Cambridge, MA. http://www.nber.org/papers/w6529.pdf

13. Evenett, S.J. and W. Keller, 2002. On Theories explaining the success of the gravity model. J. Politic. Econ., 110: 281-316. http://ideas.repec.org/p/nbr/nberwo/6529.html

14. Grant, H.J. and D.M. Lambert, 2005. Regionalism in world agricultural trade: Lessons from gravity model estimation. Proceeding of the American Agricultural Economics Association Annual Meeting, July 24-27, Providence, Rhode Island, pp: $1-31$. http://ideas.repec.org/p/ags/aaea05/19269.html

15. Helpman, E. and Krugman, P.R., 1985. Market Structure and Foreign Trade: Increasing Returns, Imperfect Competition and the International Economy. MIT Press, Cambridge, MA., ISBN: 026258087X, pp: 1-6.

16. Linnemann, H., 1966. An Econometric Study of International Trade Flows. North-Holland Pub. Co., Amsterdam.

17. Meade, J.E., 1955. The Theory of Customs Unions, Amsterdam: North Holland, ISBN: 0313223793, pp: 121.

18. Poyhonen, P., 1963. A tentative model for the flows of trade between countries. Weltwirtschaftliches Arch., 90: 93-100.

19. Rose, A.K. and E. Van Wincoop, 2001. National money as a barrier to trade: The real case for monetary union. Am. Econ. Rev., 91: 386-390. http://faculty.haas.berkeley.edu/arose/RvW.pdf

20. Soloaga, I. and A. Winters, 2000. Regionalism in the nineties: What effect on trade? Development Research Group of World Bank. http://ideas.repec.org/a/eee/ecofin/v12y2001i1p129.html

21. Tinbergen, J., 1962. Shaping the world economy; suggestions for an international economic policy. http://www.questia.com/library/book/shaping-theworld-economy-suggestions-for-an-internationaleconomic-policy-by-jan-tinbergen.jsp

22. UN Economic Commission for Europe, 2007. Regional trade integration in central Asia: The way to modernize, attract investment and new technologies. http://www.unece.org/speca/pdf/trade/BackgrdPapr Eng_session2.pdf

23. Viner, J., 1950. The Economics of Custom Unions, in the Customs Union Issues. Chapter IV, New York Carnegie Endowment for International Peace, pp: 41-81. 